free-burning smokeless fuel, by removing the greater part of the volatile matter which is responsible for most of the smoke nuisance. Appliances have been designed for the burning of such smokeless fuel. Efforts are also being made to test and modify domestic appliances so that raw coal may be burned more efficiently and with a substantial reduction of pollution.

\section{Domestic Cokes}

TrE Institute of Fuel and the Manchester Associa. tion of Gas Engineers held a symposium on domestic cokes in Manchester on November 18. Arnold Marsh examined the question from the point of view of smoke reduction and, discussing the scope of the different smokeless fuels, concluded that all forms of coke would be required. E. C. Evans, on the other hand, fears that an increase in the use of oven coke for domestic purposes would be disadvantageous to the economic production of pig iron. Even now there is a shortage of suitable blast furnace coke. H. J. Hodsman, discussing the relation between the properties of a coke and its behaviour in the grate, emphasized that shallow modern grates cannot be justified on the ground of efficiency on consuming any fuel-whether raw coal or coke. The deeper fuel bed is more rational and this is being recognized by the consumer, for E. W. L. Nicol pointed out that 70,000 such grates convenient for burning coke are sold annually. A. Blackie described two suitable designs of grate which have proved satisfactory. Emphasis was laid on the possibility of activating high-temperature cokes with soda. Prof. J. W. Cobb described how in 1925 it was observed that the reactivity of coke to carbon dioxide is enormously increased by treatment with soda. The chance of industrial use of this has been increased by P. J. Askey's observations that in presence of lime, the addition of even so little as 0.5 per cent sodium carbonate to a coke may produce an adequate increase in the reactivity. R. A. Mott described experiments made with H. H. Thomas in Liverpool Gas Works on alkali activation made under coke oven conditions. These leave little doubt that high-temperature cokes can be made to burn more actively as a result of alkali treatment; but the economic future of the process will depend on other factors. Many existing gas works would find it difficult to introduce a process of pretreating coal into their routine.

\section{Acquisitions at the British Museum (Natural History)}

Mr. W. FALConer has recently presented to the Department of Zoology males and females of eightyfour British species of spiders all new to the collection. This valuable gift makes the collection of British spiders in the Museum almost complete. Another interesting accession comprises nine spiders' webs mounted between sheets of glass, the webs being made visible by a black background and the judicious application of baby powder. Prof. G. H. F. Nuttall has presented to the Department of Entomology the whole of the material upon which he based his well-known studies on the human louse. His results, published in Parasitology (1917-30), include a very full summary of its relation to typhus, relapsing and trench fever, and other diseases which it carries, and a detailed account of methods of combating lousiness. Among other things Prof. Nuttall dernonstrated that the head louse and body louse are not distinct species, but only varieties, possibly showing slight biological differences, of a single species. Recent accessions to the Department of Geology include an extensive series of petrified cones and wood of Araucarian conifers from Patagonia, collected and presented by Dr. F. Mansfield. Many of the specimens have been cut and polished, and the preservation, in chalcedony of various colours, is very good. These fossils were found in the Cerro Alto and Cerro Cuadrado region of Santa Cruz, which has been described as one of the world's most marvellous petrified forests ; the material has not yet been fully studied, and the geological age is still uncertain, though it is probably at least as old as early Tertiary. Several hundred invertebrates, mainly corals, from the Palæozoic of Germany and Bohemia, have been collected and presented by Dr. Stanley Smith. The Mineral Department has received by exchange with the Mineralogical Museum, Moscow, an interesting series of specimens from Kola Peninsula and various localities in Central Asia. Lord Ilchester has given a series of pebbles from carefully defined points on the Chesil Beach, which is probably the most remarkable bank of shingle in the world.

\section{Exhibit of the Biology of Water-Supply}

A NEw exhibit which has been installed in the Central Hall of the British Museum (Natural History) illustrating the biology of water-supply shows, more fully than its predecessor, the influence of plants and animals on the purification of water for human use. It shows how river-water is purified by storage in reservoirs, followed by filtration through sand. Some of the organisms living in the water of a river find the conditions in waterworks more favourable, and multiply greatly. Thus great swarms of minute plants, and the animals that feed on them, arise in reservoirs. This is sometimes to the advantage of the water engineer, and sometimes greatly to his disadvantage. The beneficial effects include oxygenation of the water by the plants, and the formation of a natural filtering film, more efficient than any artificial film, in stopping the passage of bacteria. This living film, which consists chiefly of microseopic plants, forms on the surface of the sand and gravel of the filter-bed. Trouble arises if the living things in the reservoirs become so numerous as to choke the filters, or are of such a kind as to give an unpleasant flavour to the water. These points are illustrated by specimens, photographs and diagrams. History has shown that, without sand-filtration, mains and supply-pipes are apt to become seriously blocked with animal growths. This is illustrated in the exhibit, which also shows how the excessive growth of microscopic plants can be checked, how wells and springs come to give good or bad water, how sudden and severe outbreaks of 